\title{
Chronology of Significant Events
}

Important regional and national events are indicated in bold.

I8oos After first taking it on as a tax farm, the Qavams take over ownership of Aliabad.

I946 Seyyid Yaqub Askari is appointed bailiff, main agent of the landlord in Aliabad.

I946 Tudeh Party representatives come to Aliabad.

August 1953 Prime Minister Mosaddeq is overthrown in a British and American CIA-sponsored coup. The Shah, who had fled, is brought back to Iran under British and American sponsorship.

Pro-Mosaddeq and pro-Tudeh Party people in Aliabad are punished for their support of the ousted Prime Minister Mosaddeq by beatings, humiliation, imprisonment and in at least in one case, exile.

I950s The peasant strike occurs in Aliabad.

I958 Government officials attempt to seize Seyyid Ibn Ali Askari's large stash of opium in Aliabad.

1962 Implementation of land reform in Aliabad instigates peasant struggles against Seyyid Ibn Ali Askari.

August I0, 1978 Massacre by government forces at the New Mosque and other disturbances occur in Shiraz.

September 8, 1978 Martial law is imposed in Shiraz and other cities. 
November 20, 1978 Massacre occurs at Habib Mosque in Shiraz.

December 7, 1978 Stone throwing is directed by Seyyid Yaqub Askari against a convoy of vehicles carrying mourners to a town farther up the valley.

December 8, 1978 Pro-Khomeini Kurosh Amini is stabbed by his brother-in-law Mehdi, followed by people marching and shouting "Death to the Shah" in Aliabad for the first time.

December I0, 1978 Tasua, anniversary of the eve of the martyrdom of Imam Husein, is commemorated with a large revolutionary march in Shiraz.

December II, 1978 Many village men go to the large Ashura march in Shiraz, then return in a group to the Aliabad mosque.

January 5, I979 The informal group of seyyid women initiate nightly marches against the Shah's government in Aliabad.

January I6, 1979 The Shah leaves the country.

February I, 1979 Ayatollah Khomeini arrives in Tehran.

February II, 1979 The government of the Shah and Prime Minister Bakhtiar falls. Mehdi and his supporters assault Kurosh Amini's stepfather-uncle.

March 2I, I979 On this Noruz (New Year's Day), no one visits Seyyid Yaqub Askari, demonstrating the decline in his influence.

March 30-3I, 1979 A national referendum is held on whether to institute an Islamic Republic government, with possible votes of yes or no. The government reports the results as $\mathrm{T} \%$ in favor.

April I, 1979 Ayatollah Khomeini declares Iran the Islamic Republic of Iran.

May I4, 1979 Seyyid Yaqub Askari's son Seyyid Muslem is attacked by the younger brother of Fazlollah Rezai, who goes unpunished.

October 2, 1979 Seyyid Ibn Ali Askari attempts to divide up some Aliabad land among "needy" villagers who are actually his own relatives and supporters.

October 6, 1979 Seyyid Ibn Ali Askari is imprisoned due to pressure by villagers. He is released four days later. 
October II, 1979 Seyyid Ibn Ali Askari is put back in prison after demonstrations and outraged protest by villagers.

November 2, 1979 Seyyid Ibn Ali Askari's land is taken over and planted by the peasant faction.

November 4, 1979 The American embassy is occupied by radical students, and American hostages are seized.

November 16, 1979 Several hundred members of the peasant faction clean out the ditch that brings irrigation water from Darab and are threatened by attack from residents of this neighboring village due to misinformation provided by Seyyid Yaqub Askari's faction. For the first time, there are opposition marches into Aliabad with people shouting slogans against the Askaris, followed by a violent confrontation and the subsequent arrest of some of the Askari faction by the gendarmes.

November 2I, I979 On this first day of the mourning month of Moharram, self-flagellation practices intensify in Aliabad.

November 28, 1979 Seyyid Ibn Ali Askari is again released from prison.

November 29, 1979 When villagers learn of the release of Seyyid Ibn Ali from prison, they drop their Tasua mourning commemorations to protest. Assured that he would be reincarcerated, they return from Shiraz to Aliabad late at night.

November 30, 1979 The opposition monopolizes Ashura commemoration activities in a forceful demonstration of political superiority. Upon conclusion of the mourning at noon, participants march to an orchard owned by Seyyid Ibn Ali Askari and tear down the walls, then return for feasts in three village homes sponsored by opposition sympathizers. 


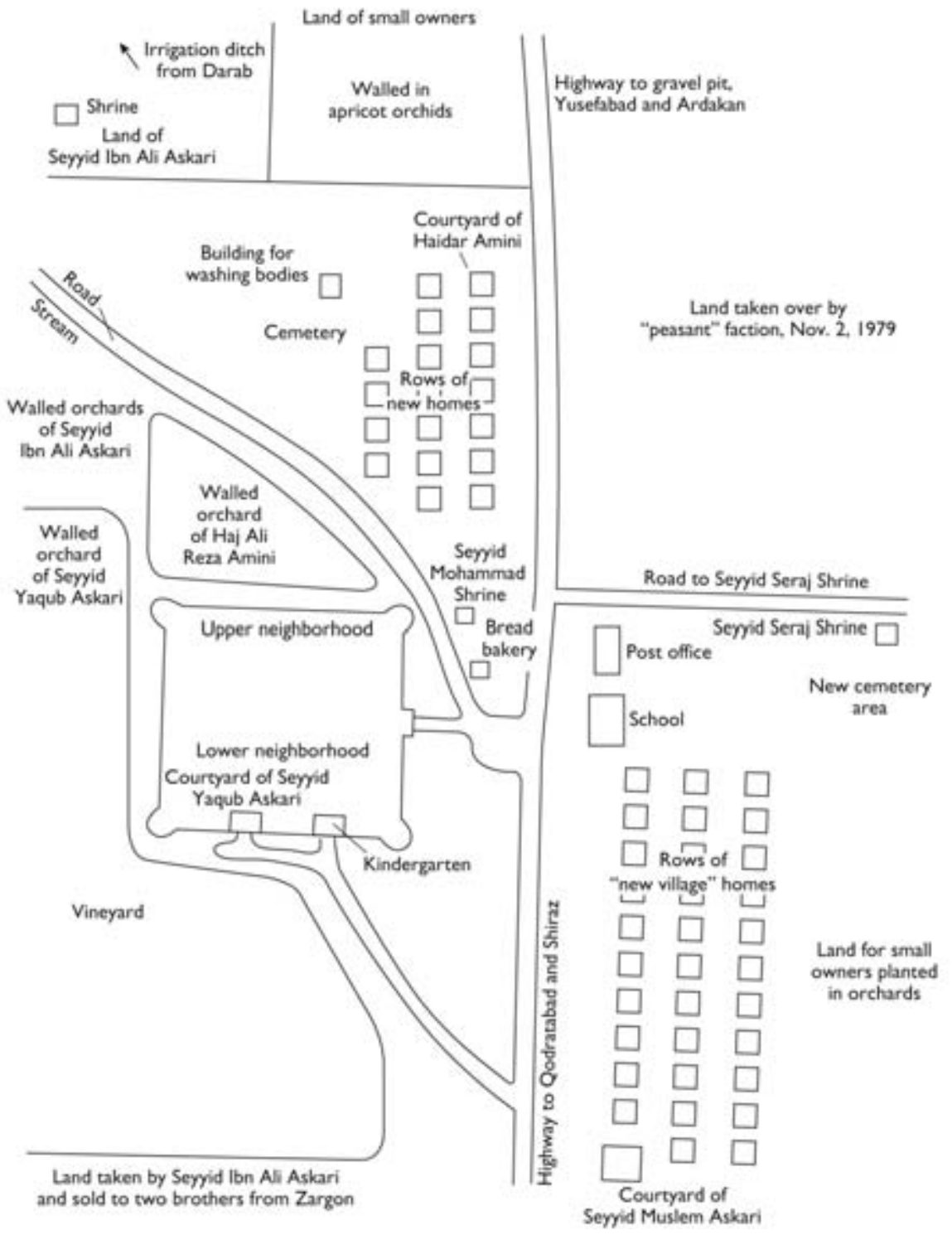

MAP 1. The walled village of Aliabad and its immediate environs, 1978-1979. 


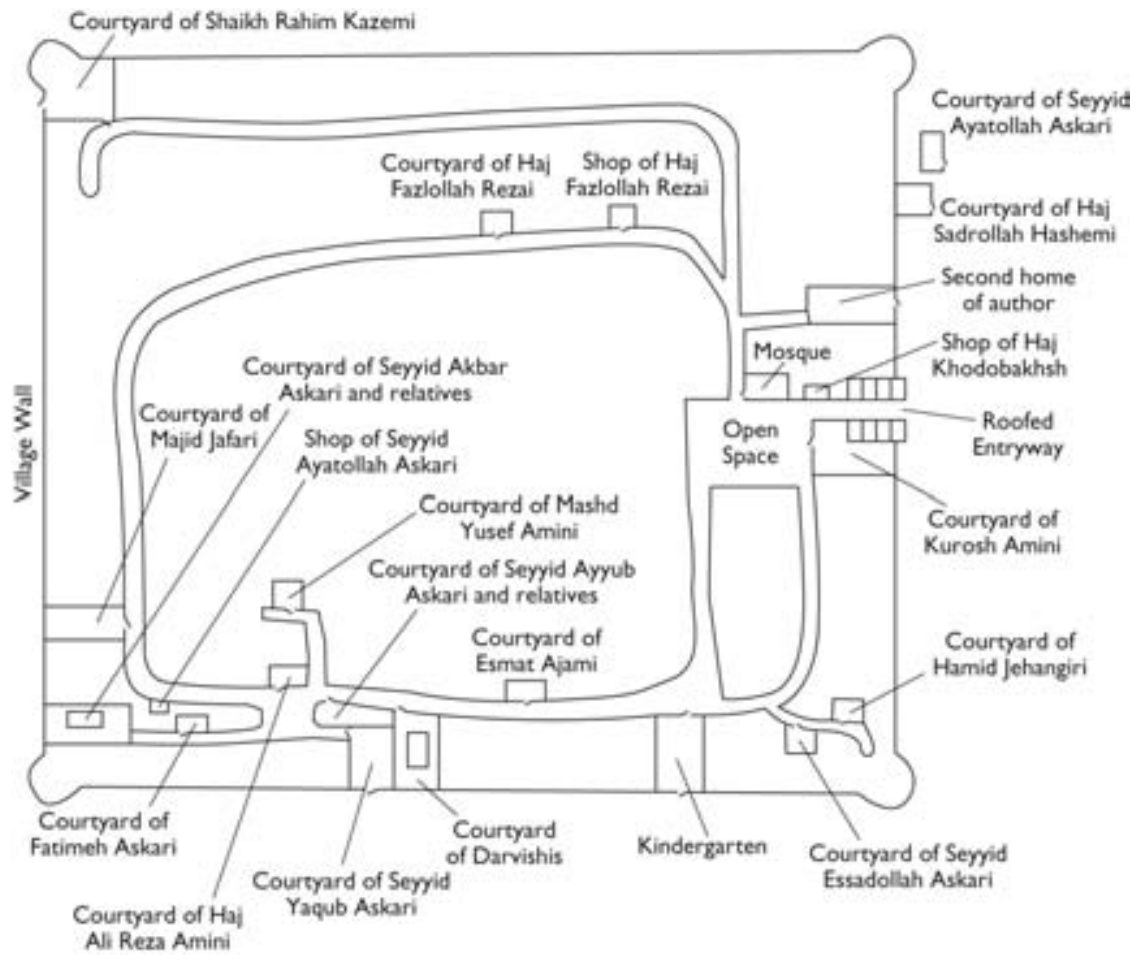

MAP 2. The walled village of Aliabad, 1978-1979. 
